Огляди літератури, оригінальні дослідження, погляд на проблему, ювілеї

УДК 616.37-002-06:616.155.194.8]-08-039.76

DOI 10.11603/1811-2471.2018.v0.i2.8564

\title{
АНАЛІЗ ДІЄВОСТІ ПРОГРАМИ РЕАБІЛІТАЦІЇ ХВОРИХ НА ХРОНІЧНИЙ ПАНКРЕАТИТ ІЗ СУПУТНЬОЮ АНЕМІЕЮ НА АМБУЛАТОРНОМУ РІВНІ ДОПОМОГИ
}

\author{
๑М. В. Палихата, Л. С. Бабінець, 3. І. Сабат, І. О. Боровик
}

ДВНЗ «Тернопільський державний медичний університет імені І. Я. Горбачевського МОЗ України»

PЕзюМЕ. Актуальною на сьогодні $\epsilon$ проблема поширення полідефіцитної анемії, яка зумовлена тим, що нестача вмісту заліза в організмі, як правило, асоціюється з дефіцитом міді, цинку, кобальту, марганцю, білка, вітамінів В і С, роль яких безпосередньо пов'язана з обміном заліза. Саме тому додатково до схеми загального лікування було запропоновано призначати комплексний залізовмісний полімінерально-вітамінний препарат по 1 капсулі двічі на день протягом місяця двічі на рік в якості реабілітаційних заходів.

Мета - провести порівняльний аналіз параметрів обміну заліза у пацієнтів з ХП у поєднанні із ЗДА у ході загальноприйнятого лікування і програми терапії з використанням комплексного залізовмісного полімінеральновітамінного препарату Ферсінол-Z.

Матеріал і методи. Було проаналізовано схеми лікування 29 обстежених хворих на ХП із супутньою анемією, які отримували лікування на базі гастроентерологічного відділення КНП “ТКМЛ № 2".

Результати. Встановили позитивну динаміку досліджуваних показників обміну заліза після лікування, порівняно з такими до лікування: рівень RBC збільшився на 14,28 \%, HGB - на 12,36 \%, КП - на 3,49 \%, НСТ - на 26,69 \%, MCV - на 9,45 \%, 3С - на 40,63 \%, НТ3 - на 55,10 \%, 333С і л33С зменшилися на 9,33 \% і 19,11 \% відповідно (р<0,05). Рівні MCV і НCT нормалізувалися, що свідчило про повну елімінацію мікроцитозу еритроцитів. Рівень Л33С також нормалізувався, що свідчило про поповнення депо заліза. Прийом препарату зумовив зменшення кількості рецидивів (загострень) ХП залежно від тяжкості клінічного перебігу хвороби:у пацієнтів із легким перебігом - $3(1,48 \pm 0,15)$ до $(0,68 \pm 0,1)$, із середнім ступенем тяжкості - $3(2,32 \pm 0,17)$ до $(1,87 \pm 0,19)$ і з тяжким - $3(4,11 \pm 0,31)$ до $(3,18 \pm 0,37)$.

Висновки. Включення комплексного залізовмісного полімінерально-вітамінного препарату Ферсінол-Z до програми комплексної реабілітації хворих на хронічний панкреатит із супутньою ЗДА привело до покращення лабораторних параметрів обміну заліза, а також до зменшення кількості рецидивів ХП, що довело дієвість запропонованого курсу реабілітації за впливом на клінічний перебіг ХП із супутньою анемією.

КЛючОВІ СЛОВА: хронічний панкреатит; залізодефіцитна анемія; полідефіцитна анемія; комплексний залізовмісний полімінерально-вітамінний препарат.

Вступ. Лікування хронічного панкреатиту (ХП), поєднаного із залізодефіцитною анемією (ЗДА), не обмежується лише медикаментозною терапією. Дуже важливою у профілактиці загострень і подовженні ремісії захворювання $\epsilon$ подальша реабілітація таких пацієнтів. Часто лікування тільки ХП не дозволяє повністю домогтися корекції анемії. Поєднання ЗДА і ХП знижує якість життя і виживання пацієнтів, збільшує кількість госпіталізацій, а також ризик ускладнень від медикаментозної терапії [1]. У даному випадку лікарі загальної практики - сімейні лікарі відіграють ключову роль у підвищенні обізнаностіпацієнта, своєчасному виявленні та профілактиці анемії, здійсненні комплексного підходу із застосуванням медикаментозних і немедикаментозних методів лікування, медичної реабілітації на амбулаторному рівні допомоги [2]. За висновками спеціалістів-гематологів, дуже актуальною на сьогодні $\epsilon$ проблема поширення полідефіцитної анемії, яка обґрунтована тим, що нестача вмісту заліза в організмі зазвичай пов'язана з дефіцитом міді, цинку, кобальту, марганцю, білка, вітамінів В і С, роль яких в організмі безпосередньо пов'язана з обміном заліза [3]. Саме тому додатково до схеми загального лікування було дода- но вживання комплексного залізовмісного полімінерально-вітамінного препарату по 1 капсулі двічі на день протягом місяця двічі на рік в якості реабілітаційних заходів.

Мета - провести порівняльний аналіз параметрів обміну заліза у пацієнтів з ХП, поєднаним із ЗДА, у ході загальноприйнятого лікування і програми терапії з використанням комплексного залізовмісного полімінерально-вітамінного препарату Ферсінол-Z.

Матеріал і методи дослідження. Під час дослідження було проаналізовано схеми лікування 29 обстежених хворих на ХП із супутньою анемі$\epsilon ю$ які лікувалися на базі гастроентерологічного відділення КНП "ТКМЛ № 2".

Результати й обговорення. Ферменти були призначені всім пацієнтам - 29 (100,0 \%); інгібітори протонної помпи (ІПП) - 25 хворим (86,2 \%); прокінетики - 16 (55,2 \%); спазмолітики - 23 (79,31\%); Н $_{2}$-блокатори гістамінових рецепторів 3 (10,34\%); антациди, обволікаючі і в'яжучі - 7 (24,13\%); антихолінергічні препарати - 3 (10,34\%); антибактеріальні препарати - 5 (20,69\%); пробіотики - 2 (6,9\%); нейролептики - 4 (13,8 \%); гепатопротектори - 9 (31,0\%); вітаміни ( $\left.\mathrm{B}_{1}, \mathrm{~B}_{6}, \mathrm{~B}_{12}, \mathrm{C}\right)-13$ 
Огляди літератури, оригінальні дослідження, погляд на проблему, ювілеї

(44,82\%); амінокислоти (берлітіон, діаліпон, тівортін, глутаргін) - 8 (31,03 \%) особам. Варто зазначити, що лише у двох випадках було призначено препарати заліза, а діагноз анемії в стаціонарі було діагностовано лише в 4 (13,8 \%) випадках. Після проведеного курсу загальноприйнятого лікування відмічали незначне покращення показників анемічного синдрому: НGB підвищився до

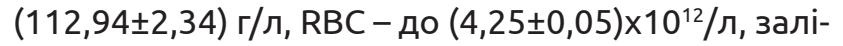
зо сироваткове - до $(12,3 \pm 0,95)$ мкмоль/л, 333С зменшилася до $(65,24 \pm 1,57)$ ммоль/л $(p<0,05)$. Однак домогтися повної корекції анемії не вдалося, що і спонукало нас до включення в комплекс лікування додаткових засобів, а саме - комплексного залізовмісного полімінерально-вітамінного препарату Ферсінол - Z. Пацієнтам було призначено додатково до загального лікування вживання препарату по 1 капсулі двічі на день впродовж місяця двічі на рік, після чого зроблено повторний загальний аналіз крові та визначено біохімічні показники обміну заліза. Було виявлено позитивну динаміку досліджуваних показників після лікування, порівняно з такими до лікування: рівень RBC збільшився на 14,28 \%, НGB - на 12,36 \%, КП - на $3,49 \%$, НСТ - на 26,69 \%, MCV - на 9,45 \%, 3С - на 40,63 \%, НТ3 - на 55,10 \%, 333С і л33С зменшили-

\section{ЛІТЕРАТУРА}

1. Хронический панкреатит: работа над ошибками // Н. Б. Губергриц, Н. В. Беляева, А. Е. Клочков, П. Г. Фоменко // Сучасна гастроентерологія. - 2015. - № 3 (83). C. 97-104.

2. Наказ МОЗ України від 2 листопада 2015 р. № 709 / Уніфікований клінічний протокол первинної та

\section{REFERENCES}

1. Gubergrits, N.B., Belyaeva, N.V., Klochkov, A.E., \& Fomenko, P.G. (2015). Khronicheskiy pankreatit: rabota nad oshybkami [Chronic pancreatitis: work on mistakes]. Suchasna hastroenterolohiia - Modern Gastroenterology, 3 (83), 97-104 [in Russian].

2. Unifikovanyi klinichnyi protokol pervynnoi ta vtorynnoi (spetsializovanoi) medychnoi dopomohy "Zalizodefitsytna anemiia" No. 709 [Unified clinical protocol of primary and secondary (specialized) medical aid "Iron deficiency anemia" ся на 9,33 \% і 19,11 \% відповідно (p<0,05). Рівні MCV і НCT нормалізувалися, що свідчило про повну елімінацію мікроцитозу еритроцитів. Рівень Л33С також нормалізувався, що свідчило про поповнення депо заліза. Прийом препарату привів до зменшення кількості рецидивів (загострень) ХП в залежності від тяжкості клінічного перебігу захворювання: у пацієнтів із легким перебігом - 3 $(1,48 \pm 0,15)$ до $(0,68 \pm 0,1)$, із середнім ступенем тяжкості - $3(2,32 \pm 0,17)$ до $(1,87 \pm 0,19)$ і тяжким - 3 $(4,11 \pm 0,31)$ до $(3,18 \pm 0,37)(p<0,05)$.

Висновки. Включення комплексного залізовмісного полімінерально-вітамінного препарату Ферсінол-Z до програми комплексної реабілітації хворих на хронічний панкреатит із супутньою ЗДА привело до покращення лабораторних параметрів обміну заліза, а також до зменшення кількості рецидивів ХП, що довело дієвість запропонованого курсу реабілітації за впливом на клінічний перебіг ХП із супутньою анемією.

У перспективі подальших досліджень плануємо розробити нові реабілітаційні програми для пацієнтів із ХП у поєднанні з анемією, поєднуючи прийом залізовмісного полімінерально-вітамінного препарату із фізіотерапевтичними методами, а також з рефлексотерапією.

вторинної (спеціалізованої) медичної допомоги «Залізодефіцитна анемія".

3. Мазуренко І. К. Консервовані продукти для харчування дітей, хворих на залізодефіцитну анемію / І. К. Мазуренко // Прогресивні техніка та технології харчових виробництв ресторанного господарства і торгівлі. - 2010. - Вип. 2 (12). - С. 443-447.

No. 709]. (2015). Nakaz MOZ Ukraiiny - Order of the Ministry of Health of Ukraine [in Ukrainian].

3. Mazurenko, I.K. (2010). Konservovani produkty dlia kharchuvannia ditei, khvorykh na zalizodefitsytnu anemiiu [Canned food for children suffering from iron deficiency anemia]. Prohresyvni tekhnika ta tekhnolohii kharchovykh vyrobnytstv restorannoho hospodarstva itorhivli-Progressive Technique and Technologies of Food Production of Restaurant Economy and Trade, 2 (12), 443-447 [in Ukrainian]. 


\title{
АНАЛИЗ ДЕЙСТВЕННОСТИ ПРОГРАММЫ РЕАБИЛИТАЦИИ БОЛЬНЫХ ХРОНИЧЕСКИМ ПАНКРЕАТИТОМ С СОПУТСТВУЮЩЕЙ АНЕМИЕЙ НА АМБУЛАТОРНОМ УРОВНЕ помОщи
}

\author{
๑М. В. Палихата, Л. С. Бабинец, З. И. Сабат, И. О. Боровик
}

ГВУЗ «Тернопольский государственный медицинский университет имени И. Я. Горбачевского Мз Украины»

РЕЗЮМЕ. Актуальной сегодня является проблема распространения полидефицитной анемии, которая обусловлена тем, что недостаток содержания железа, как правило, связан с дефицитом меди, цинка, кобальта, марганца, белка, витаминов В и С, роль которых в организме непосредственно связана с обменом железа. Именно поэтому дополнительно к схеме общего лечения было добавлено употребление комплексного железосодержащего полиминерально-витаминного препарата по 1 капсуле два раза в день в течение месяца дважды в год в качестве реабилитационных мероприятий.

Цель - провести сравнительный анализ параметров обмена железа у пациентов с ХП в сочетании с ЖДА в ходе общепринятого лечения и программы терапии с использованием комплексного железосодержащего полиминерально-витаминного препарата Ферсинол-Z.

Материал и методы. Были проанализированы схемы лечения 29 обследованных больных ХП с сопутствующей анемией, лечившихся на базе гастроэнтерологического отделения КНП "ТКГБ № 2". Установили положительную динамику исследуемых показателей обмена железа после лечения, по сравнению с таковыми до лечения: уровень RBC увеличился на 14,28 \%, HGB - на 12,36 \%, КП - на 3,49\%, НСТ - на 26,69 \%, MCV - на 9,45 \%, жС - на 40,63 \%, НТЖ - на 55,10 \%, З3СС и ЛЗСС уменьшились на 9,33 \% и 19,11\% соответственно (р<0,05). Уровни МСV и НСТ нормализовались, что показало полную элиминацию микроцитоза эритроцитов. Уровень ЛЗСС также нормализировался, что свидетельствует о пополнении депо железа. Прием препарата обусловил уменьшение количества рецидивов (обострений ХП) в зависимости от тяжести клинического течения ХП: у пациентов с легким течением - с $(1,48 \pm 0,15)$ до $(0,68 \pm 0,1)$, со средней степенью тяжести - с $(2,32 \pm 0,17)$ до $(1,87 \pm 0,19)$ и тяжелым - с $(4,11 \pm 0,31)$ до $(3,18 \pm 0,37)$.

Выводы. Включение комплексного железосодержащего полиминерально-витаминного препарата Ферсинол-Z в программу комплексной реабилитации больных хроническим панкреатитом с сопутствующей ЖДА привело к улучшению лабораторных параметров обмена железа, а также к уменьшению количества рецидивов ХП, доказало действенность предложенного курса реабилитации по влиянию на клиническое течение ХП с сопутствующей анемией.

КЛЮЧЕВЫЕ СЛОВА: хронический панкреатит; железодефицитная анемия; полидефицитная анемия; комплексный железосодержащий полиминерально-витаминный препарат.

\section{ANALYSIS OF THE REHABILITATION PROGRAM ACTIVITY FOR PATIENTS WITH CHRONIC PANCREATITIS AND RELATED ANEMIA AT THE AMBULATORY LEVEL}

\section{@M. V. Palykhata, L. S. Babinets, Z. I. Sabat, I. O. Borovyk \\ I. Horbachevsky Ternopil State Medical University}

SUMMARY. Problem of polydefinitic anemia prevalence is very topical today. It is justified by the fact that the insufficiency of iron in the body is usually associated with deficiency of copper, zinc, cobalt, manganese, protein, vitamins $B$ and $C$, whose role in the body is directly related to the exchange of iron. That is why, the use of a complex ironcontaining polymineral-vitamin preparation was supplemented by 1 capsule twice a day for a month twice a year in addition to the general treatment scheme, as rehabilitation measures.

The aim - to conduct a comparative analysis of iron metabolism parameters in patients with CP in combination with IDA in the course of conventional treatment and therapy program using a complex iron-containing polymineral-vitamin preparation Fersinol-Z.

Materials and Methods. The treatment regimens of 29 examined patients with CP and concomitant anemia who were treated on the basis of the Gastroenterological Department of the Ternopil Clinical Town Hospital No. 2 were analyzed. The positive dynamics of the studied iron exchange rates after treatment was compared with those before treatment: the level of RBC increased by $14.28 \%$, HGB - by $12.36 \%, \mathrm{KP}$ - by $3.49 \%, \mathrm{HCT}$ by $26.69 \%$, MCV by $9.45 \%$, IS by $40.63 \%$, SOT by $55.10 \%$, IBAS and LIBAS decreased by $9.33 \%$ and $19.11 \%$ respectively $(p<0.05)$. The levels of MCV and HCT were normalized, which testified complete elimination of red cell cytosis. The level of LIBAS also normalized, which testifyed the replenishment of the iron depot. Admission of the drug leds to a reduction of CP's exacerbations, depending on the severity of the clinical course of CP: in patients with mild course - from (1.48 \pm 0.15$)$ to $(0.68 \pm 0.1)$, with an average degree of severity - from $(2.32 \pm 0.17)$ to $(1.87 \pm 0.19)$ and severe - from $(4.11 \pm 0.31)$ to $(3.18 \pm 0.37)$.

Conclusion. The inclusion in the program of complex rehabilitation of chronic pancreatitis with concomitant ZDA of complex iron-containing polymineral-vitamin preparation Fersinol-Z has led to an improvement of laboratory parameters of iron exchange, as well as to a decrease in the number of recurrences of $\mathrm{CP}$, which proved the effectiveness of the proposed course of rehabilitation for influencing the clinical course of CP with concomitant anemia.

KEY WORDS: chronic pancreatitis; iron-deficiency anemia; polydeficiency anemia; complex iron-containing polymineral-vitamin preparation. 